\title{
EFEKTIFITAS MODEL PEMBELAJARAN KONTEKSTUAL SPRM BERBASIS VISUALISASI ASSEMBLING DALAM PENINGKATAN KOMPETENSI
}

\author{
Harjanti \\ STIKes Mitra Husada Karanganyar \\ HarjantiMHK@gmail.com
}

\begin{abstract}
This study aimed to the effective application of contextual learning model-based visualization SpRM assembling to increased competency. Research the type of experiment. The sample consisted of 60 students, 30 students of class $A$ as the control group, class B 30 students as an experimental group using simple random sampling technique. Instruments practice case studies, data collection methods and testing techniques unstructured interview. Results of research effectiveness test results showed that there was an average difference of significance between students who use visualization and that does not use visualization in solving the case.
\end{abstract}

Keywords: Efektitas, Contextual Learning Model, Visualization

\begin{abstract}
Abstrak
Tujuan penelitian mengetahui efektifitas penerapan model pembelajaran kontekstual SPRM berbasis visualisasi assembling terhadap peningkatan kompetensi. Jenis Penelitian eksperimen. Besar sampel adalah 60 mahasiswa D3 RMIK Mitra Husada Karanganyar yang terdiri dari 30 mahasiswa (klas A) sebagai kelompok control, 30 mahasiswa (klas B) sebagai kelompok eksperimen menggunakan tehnik simple random sampling. Instrumen penelitian adalah kasus praktik dengan metode pengumpulan data menggunakan tehnik tes dan wawancara tidak terstruktur. Hasil penelitian menunjukkan ada perbedaan rata-rata signifikasi antara mahasiswa yang menggunakan visualisasi dan yang tidak menggunakan visualisai dalam menyelesaikan kasus $(\mathrm{p}=0.001)$. Visualisasi membuat mahasiswa lebih memahami materi, mudah dalam pengerjaan kasus, membantu belajar untuk UTS dan UAS, memberikan gambaran pelaksanaan alur dokumen rekam medis di Rumah Sakit.
\end{abstract}

Kata Kunci: Efektitas, Model Pembelajaran Kontekstual, Visualisasi

\section{PENDAHULUAN}

Berdasarkan Peraturan Menteri Kesehatan RI No. 55 Tahun 2013 tentang penyelenggaraan pekerjaan Perekam Medik pasal 13, dalam pelaksanaan pekerjaan perekam medis mempunyai kewenangan sesuai dengan klasifikasi pendidikan diantaranya yaitu melaksanakan kegiatan pelayanan pasien dalam manajemen dasar rekam medis dan informasi kesehatan.

Kegiatan pelayanan pasien yang dilakukan oleh perekam medis salah satunya yaitu pada unit assembling, dimana pelayanan pasien dilakukan dengan meneliti kelengkapan dokumen pasien sebagai bentuk upaya menjaga keselamatan pasien. Dimana dari dokumen rekam medis tersebut, pemberi pelayanan kesehatan mengetahui riwayat penyakit pasien terdahulu, pasien alergi dengan obat apa saja, Dokter yang merawat/ yang bertanggung jawab dll. Maka kelengkapan dokumen rekam medis harus dijamin kelengkapannya, sehingga pemberi pelayanan kesehatan tidak salah dalam merawat/ melayani pasien.

Mengingat begitu pentingnya pekerjaan perekam medis, maka seorang Dosen terutama Dosen Mata Kuliah kompetensi Sistem Pengelolaan Rekam Medis (SPRM) mampu memberikan materi yang mudah dipahami dan dimengerti oleh Mahasiswa. Dengan demikian diharapkan mahasiswa mampu menguasai dan menerapkan ilmu yang dimiliki ketika mereka praktik lapangan ataupun memasuki dunia kerja.

Salah satu bentuk upaya yang dapat dilakukan oleh seorang Dosen tersebut yaitu dengan merubah model pembelajaran yang diterapkan atau mampu menciptakan suatu kreatifitas terhadap model pembelajaran yang dilakukan. Perubahan model 
pembelajaran pernah dilakukan oleh Harjanti,dkk (2014) dengan judul model pembelajaran SPRM berbasis visualisasi assembling untuk meningkatkan kompetensi praktik laboratorium yaitu dengan merubah model pembelajaran praktik SPRM dilaboratorium dengan menggunakan visualisasi berupa video tentang alur pelayanan dokumen rekam medis dibagian assembling. Berdasarkan uji validasi diketahui skor validasi ahli materi 4,6 kategori sangat baik, validasi ahli media 4,57 kategori sangat baik, uji coba satu-satu 4,78 kategori baik, uji coba kelompok kecil 3,98 kategori baik dengan kesimpulan layak diproduksi dengan revisi. Sehingga hasil produk akan dilakukan uji efektifitas untuk mengetahui apakah model pembelajaran yang baru lebih efektif dibandingkan dengan model pembelajaran yang sudah diterapkan.

Adapun tujuan dari penelitian ini yaitu dengan melakukan mengetahui efektifitas penerapan model pembelajaran kontekstual SPRM berbasis visualisasi assembling terhadap peningkatan kompetensi

\section{METODE PENELITIAN}

Jenis penelitian yaitu eksperimen dengan 2 variabel yang terdiri dari model pembelajaran dan peningkatan kompetensi praktik laboratorium. Populasi seluruh mahasiswa semester III yang sudah mendapatkan materi SPRM, sampel 30 mahasiswa kelas A sebagai kelompok kontrol sedangkan 30 mahasiswa kelas B sebagai kelompok eksperimen menggunakan tehnik simple random sampling, dimana pemilihan sampel dilakukan secara acak tanpa memperhitungkan strata. Instrumen penelitian berupa kasus praktik untuk menguji tingkat pemahaman mahasiswa tentang alur prosedur alur dokumen mahasiswa, sedangkan metode pengumpulkan data dengan wawancara tidak terstruktuk dan tehnik tes. Nilai hasil pengerjaan kasus di uji normalitas dengan uji kolmogrov sminrov. Analisis data uji efektifitas dengan independent $t$-test. Selanjutnya hasil t hitung dibandingkan dengan $t$ tabel, tabel t yang digunakan dengan derajat bebas $(\mathrm{df}=\mathrm{db}=\mathrm{dk})=\mathrm{n}-1$. Apabila $\mathrm{t}$ hitung $>\mathrm{t}$ tabel, maka Ho ditolak, dan menerima Ha. Artinya ada beda secara signifikan antara ratarata kelompok kontrol dengan kelompok eksperimen (Riwidikdo, 2009). Untuk mendukung hasil uji statistic dilakukan wawancara kepada mahasiswa tentang metode pembelajaran yang baru.

\section{HASIL DAN PEMBAHASAN}

Uji efektifitas model pembelajaran berbasis visualisasi dilakukan dengan membandingkan antara kelompok kontrol dengan kelompok eksperimen. Kedua kelompok dilakukan perlakukan yang berbeda, dimana kelompok kontrol diperlakukan dengan menggunakan model pembelajaran yang lama yaitu mahasiswa dilakukan dengan review materi sesuai dengan teori, demonstrasi praktik, responsi dan pengerjaan kasus, sedangkan kelompok eksperimen untuk kegiatan demonstrasi praktik diganti dengan pemutaran visualisasi dan dilanjutkkan untuk mengerjakan kasus.

Dari masing pengerjaan kasus dari kelompok control dan eksperimen dikoreksi, dari hasil koreksi ditemukan bahwa untuk model pembelajaran lama pada pengerjaan kasus mahasiswa tidak mengerjakan hasil perhitungan Incomplete Medical Record (IMR) ataupun Delique Medical Record (DMR). Selain itu untuk buku dan catatan yang digunakan pada pelaksanaan alur pelayanan dokumen rekam medis dbagian assembling tidak disebutkan seperti buku ekspedisi, kartu kendali, dan lain-lain. Sedangkan pada metode pembelajaraan dengan visualisasi hasil koreksi menyatakan bahwa hasil perhitungan dikerjakan secara lengkap, pada alur pelaksanaan dikerjakan secara runtut serta buku dan catatan yang digunakan juga disertakan dengan lengkap.

Hasil koreksi selanjutnya nilai yang diperoleh dari masing-masing kelompok dilakukan uji normalitas data menggunakan uji kolmogrov sminrov dengan hasil nilai Z hitung adalah 1, 230. Nilai signifikasi (Asymp. Sig) besarnya 0, 97 dibandingkan dengan $\alpha=0,05$, sehingga signifikasi ( $p>0,05)$ dengan demikian Ho diterima yang artinya data berdistribusi normal. Setelah diketahui bahwa data yang diuji adalah berdistribusi normal maka tahap selanjutnya yaitu dilakukan uji efektifitas menggunakan uji statistik independent t-test. Hasil uji efektifitas menunjukkan bahwa nilai t hitung sebesar $-7,674$, sedangkan nilai signifikasinya adalah 0,000 hal ini menunjukkan Ho ditolak yang artinya ada perbedaan rata-rata signifikasi antara mahasiswa yang menggunakan visualisasi dan yang tidak menggunakan visualisai dalam menyelesaikan kasus. Sehingga dapat diketahui bahwa metode pembelajaran kontekstual dengan visualisasi berupa video tersebut lebih efektif dibandingkan dengan metode pembelajaran lama. 
Menurut Heinich (dalam Pribadi dan Putri 2001) video termasuk media yang diproyeksikan. Video menampilkan unsur gambar (visual) dan suara (audio) secara bersamaan sehingga mampu mengungkapkan obyek atau peristiwa secara sesungguhnya. Dengan perancanaan yang baik maka akan membuat proses komunikasi (pembelajaran) menjadi efektif.

Visualisasi tersebut digunakan upaya Dosen dalam menyeragamkan contoh demontsrasi yang seragam untuk semua pengampu praktik SPRM yang dilakukan dilaboratorium. Dengan adanya penyeragaman bentuk media pembelajaran yang digunakan input yang diberikan kepada mahasiswa sama, sehingga diharapkan output yang dihasilkan sama yaitu kompetensi sebagai Perekam Medis yang diharapkan juga terpenuhi, Hal ini seperti yang diungkapkan oleh Witara (2010) manfaat adanya media pembelajaran ini adalah penyampaian materi pembelajaran dapat diseragamkan, proses pembelajaran menjadi lebih jelas dan menarik, proses pembelajaran menjadi lebih interaktif, efisiensi dalam waktu dan tenaga, meningkatkan kualitas hasil belajar siswa, media memungkinkan proses belajar dapat dilakukan di mana dan kapan saja, media dapat menumbuhkan sikap positif siswa terhadap proses belajar, mengubah peran guru ke arah yang lebih positif dan produktif.

Fasilitas yang diberikan untuk mahasiswa juga merupakan suatu bentuk upaya yang dilakukan untuk mengajarkan mahasiswa mampu belajar secara mandiri, sehingga walaupun tidak ada Dosen pendamping mahasiswa masih bisa belajar. Seperti menurut Brown and Atkins (1988) salah satu cara peningkatan pembelajaran di laboratorium yaitu dengan cara memfasilitasi mahasiswa. Pembelajaran di laboratorium sedapat mungkin dapat membuat mahasiswa belajar secara mandiri dan saling belajar dengan temannya.

Sedangkan berdasarkan wawancara dengan mahasiswa diketahui bahwa mereka lebih menyukai metode pembelajaran yang baru, karena mempermudah pemahaman materi, alur prosedur serta buku apa saja yang digunakan lebih jelas sehingga dalam pengerjaan kasus ada gambaran tentang runtutan kegiatan yang dilakukan serta prasarana yang digunakan. Berdasarkan hasil penggunaaan waktu, mulai dari responsi sampai dengan pengerjaan kasus dengan menggunakan metode pembelajaran kontekstual berbasis visualisasi lebih cepat dibandingkan dengan metode pembelajaran lama sehingga tidak memakan waktu dan mahasiswa tidak bosan karena menunggu waktu giliran untuk dikoreksi hasil pengerjaan kasus. Dengan adanya video juga membantu dosen untuk melaksanakan demonstrasi, jadi dosen tidak perlu mengulang lagi kesetiap anak dan semua anak dapat menyaksikan demonstrasi dari video secara mandiri. Karena dari hasil penelitian lama oleh Harjanti, dkk (2014) diketahui bahwa ada sebagian Dosen ada yang menggunakan demostrasi ada yang tidak, sehingga ada mahasiswa sama sekali tidak punya gambaran mengerjakan kasus ataupun praktik sehingga nilai yang dihasilkan juga tidak memenuhi standar.

Penerapan visualisasi ini juga dapat membantu mahasiswa ketika menghadapi ujian tengah semester (UTS) ataupun ujian akhir semester (UAS) karena mahasiswa dapat memutar ulang hasil visualisasi yang ada, karena tidak mungkin mahasiswa mengingat semua alur prosedur pelayanan rekam medis yang sudah diajarkan.

Dengan adanya video tersebut juga dapat membantu mahasiswa ketika akan praktik dilahan, mereka bisa memutar ulang video sebagai referensi sebelum praktik. Karena didalam video tersebut berisi pelaksanaan alur dokumen rekam medis di Rumah Sakit, sehingga mahasiswa punya gambaran bagaimana pelaksanaan alur rekam medis di Rumah Sakit.

Sehingga metode pembelajaran yang ditawarkan yaitu metode pembelajaran kontekstual yaitu yaitu suatu proses pembelajaran yang mengkaitkan antara materi pembelajaran dengan kehidupan sehari-hari sehingga mahasiswa mampu membuat hubungan antara pengetahuan dalam kehidupan nyata (Trianto, 2007). Pengaitan ini dilakukan dengan pembuatan visualisasi sesuai dengan alur yang dilaksanakan di Rumah Sakit, sehingga ketika mahasiswa praktik di lapangan/ lahan Rumah Sakit tidak kesulitan karena sudah punya gambaran tentang pelaksanaan alur rekam medis di Rumah Sakit.

Disarankan untuk dilakukan uji efektifitas sampai tahap pelaksanaan praktik karena pada hasil uji efektifitas baru pada tahap pengerjaan kasus dan untuk pembuatan visualisasi tentang alur dokumen rekam medis di unit yang lain seperti Tempat Pendaftaran Pasien (TPP), Filing, Koding dan Analising Reporting mengingat model pembelajaran yang diterapkan lebih efektif dibanding metode yang lama. 


\section{SIMPULAN}

1. Hasil uji efektifitas menunjukkan bahwa nilai t hitung sebesar $-7,674$, sedangkan nilai signifikasinya adalah 0,000 hal ini menunjukkan Ho ditolak yang artinya ada perbedaan rata-rata signifikasi antara mahasiswa yang menggunakan visualisasi dan yang tidak menggunakan visualisai dalam menyelesaikan kasus.

2. Visualisasi membuat mahasiswa lebih memahami materi, mudah dalam pengerjaan kasus, membantu belajar untuk UTS dan UAS, memberikan gambaran pelaksanaan alur dokumen rekam medis di Rumah Sakit.

\section{DAFTAR PUSTAKA}

Arsyad, A. 2002. Media Pembelajaran, edisi 1. Jakarta: PT. Raja Grafindo Persada

Angkowo, R \& Kosasih, A. 2007. Optimalisasi Media Pembelajaran. Jakarta: PT. Grasindo

Azwar, S. 2011. Tes Prestasi: Fungsi Pengembangan Pengukuran Prestasi Belajar: Yogyakarta: Pustaka Belajar

Brown and Atkins. 1988. Effective Teaching in Higher Education. London: Mathuen

Depdiknas. 2002. Pendekatan Kontekstual dalam Pembelajaran. Jakarta: Depdiknas

2003. Pendekatan Kontekstual. Jakarta: Dirjen Dikti Direktorat Pembinaan Tenaga Kependidikan dan Ketenagaan Perguruan Tinggi

Departemen Kesehatan Republik Indonesia. 2006. Pedoman Penyelenggaraan \& Prosedur Rekam Medik Rumah Sakit. Jakarta: Direktorat Jendral Bina Pelayanan Medik

Harjanti, dkk. 2014. Model Pembelajaran SPRM Berbasis Visualisasi Assembling untuk Meningkatkan Kompetensi Praktik
Laboratorium. Dalam jurnal Manajemen Informasi Kesehatan Indonesia. apTIRMIK

Nurhadi, Y. B\& Senduk, A. G. 2004. Pembelajaran Kontekstual (Contextual Teaching and Learning/ CTL) dan Penerapannya dalam KBK. Malang: UM Press

Pribadi, B.A\& Putri, D. P. 2001. Media Pembelajaran Interaktif. Jakarta : Maju Jaya Press

Rahayuningsih, E \& Dwiyanto, J. 2005. Pembelajaran di Laboratorium. Yogyakarta: Pusat Pendidikan Pengembangan UGM

Riwindikdo, H. 2009. Statistik Kesehatan. Yogyakarta: Mitra Cendikia Press

Sanjaya, W. 2008. Perencanaan dan Desain Sistem Pembelajaran. Jakarta: Kencana Prenada Media Group

Sukmadinata, NS. 2010. Pengembangan Kurikulum. Bandung : PT.Remaja Rosdakarya

Sugiyono. 2011. Metodologi Penelitian Kuantitatif, Kualitatif dan R\&D. Bandung : CV Alfabeta

Trianto. 2007. Model-Model Pembelajaran Inovatif Berorientasi Konstruktivistik. Jakarta: Prestasi Pustaka

Witara, Dyah. 2008. Aplikasi Media Flash Untuk Meningkatkan Prestasi Siswa dalam http:// repository-usu.ac.id/media/prestasi diakses tanggal 03 September 2015 Jam 08.00 WIB

Wati, U. A. 2010. Pengembangan Multimedia Pembelajaran untuk Mata Kuliah Pembelajaran Terpadu. Dalam Jurnal Penelitian Ilmu Pendidikan Tahun 1 Volume 1 September 2010. Yogyakarta: UNY

Wirawan, I. M. A dan Ratnaya, I. G. 2011. Pengembangan Desain Pembelajaran Mobile Learning Management System pada Materi Pengenalan Komponen Jaringan. Dalam Jurnal Penelitian dan Pengembangan Pendidikan. Lembaga Pendidikan Undiksha 